\title{
Food waste in animal feed with a focus on use for broilers
}

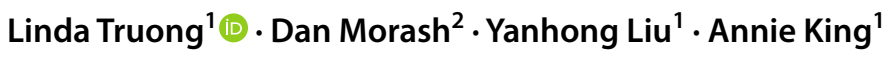

Received: 25 December 2018 / Accepted: 8 June 2019 / Published online: 15 June 2019

(c) The Author(s) 2019

\begin{abstract}
Purpose Although the world's food production is approximately 3.99 billion metric tons, one in nine people remain malnourished. In combination with the projected world population of nine billion by 2050 , further malnourishment of both humans and animals may occur; therefore, understanding of the current status of food waste and reuse is important.

Methods An extensive literature review was conducted to quantify food waste by weight and percentage at harvesting, processing/manufacturing, wholesale, retail, and consumer sectors of the food supply chain. The analysis of food waste was considered globally, within the United States, and within the state of California (USA).

Results Large amounts of food waste (meat, vegetables, fruits, and breads) are produced daily. Results of the previous research suggest that food waste can be used successfully in diets of monogastric animals.

Conclusions The poultry industry is growing globally and uses large amounts of corn and soy for poultry diets; therefore, research should be conducted to investigate the partial use of alternative feed ingredients to meet the growing demand for poultry production. We proposed that food waste, occurring in all sectors of the food supply chain, could become a partial substitute for corn and soy in broiler diets.
\end{abstract}

Keywords World food supply $\cdot$ Food waste $\cdot$ Broiler $\cdot$ Feed ingredient

\section{Introduction}

Variations in food production, distribution, and consumption have led to exorbitant food waste around the world. The continued production of waste and concomitant movement of people from rural to urban habitation are compounding factors. Researchers predict that $\sim 68 \%$ of the world's population will live in urban environments by 2050 , leaving only $\sim 30 \%$ to supply the immense amounts of fruits, vegetables, and meat products for themselves and urbanites (UN 2018). In 2016, an estimated $11 \%$ of the United States' (US) population was employed in food production and related industries (USDA-ERS 2018b). Inputs (physical work, land use, and supplements) and food are being wasted at harvest, processing/manufacturing, wholesale, retail, and consumer levels with 22\% of unused food relocated to landfills (Buzby and Hyman 2012; US-EPA 2016b). Food waste terminology,

Linda Truong

lxtru@ucdavis.edu

1 Department of Animal Science, University of California, Davis 95616, USA

2 California Safe Soil, LLC, Mcclellan 95652, USA those most affected by food waste, its production, as well as general and specific methods for preventing and reclaiming loss, especially at retail, are discussed below.

\section{Food waste}

\section{Definition of food waste}

Food waste can be avoided or not throughout the food supply chain. Avoidable waste is that which could be readily made into useful products but is ultimately discarded in landfills. Unavoidable waste designates portions of food which cannot be eaten by humans, such as some fruit and vegetable peels, fish bones, and egg shells. However, unavoidable waste can be made into useful products as well (Lewis et al. 2017). Thus, food waste can be viewed as a reflection on human behavior rather than food quality (Parfitt et al. 2010). In this manuscript, 'food waste' will be defined as 'the difference between the amount of food produced and the sum of all food employed in any kind of productive use, whether it is food or nonfood" (Bellemare et al. 2017). In other words, food waste is the amount of food material produced and 
ultimately discarded during any stage of the food supply chain (Dou et al. 2016). 'Food waste' will also be interchangeable with 'food loss' as there is no formal distinction between the two in the literature. Food insecurity often has an inverse relationship with food waste. Food insecurity is defined as having difficulty providing adequate food for members in a household during any given time. If food is lacking for prolonged periods of time, it is chronic food insecurity (Coleman-Jensen et al. 2012).

\section{Terminology along the food chain}

Particular terms are associated with food waste due to where it occurs throughout the food supply chain. Harvest loss is the food that is discarded directly from the farm. Food items are generally discarded due to poor standard appearance, damage, or un-ripened status (if of horticultural origin) (Parfitt et al. 2010). During processing/manufacturing, food is generally cleaned, dehulled, dried, milled, packaged, or mixed. Depending on the desired end-product, much of the original fruit, vegetable, grain, or animal could be discarded. Also, loss at the processing/manufacturing stage could be attributed to possible contaminations or poor manufacturing techniques and/or malfunctioning equipment during processing (Parfitt et al. 2010; King 2013). At wholesale, food is stored and sold in mass quantities. Wholesale loss is plagued by short shelf-life, low demand, incorrect labeling, or failures in the cold chain (Lewis et al. 2017). Similar issues are observed at retail (sale of small quantities to the public) where loss occurs due to bruises, torn packages, as well as near, present, or past sell-by dates (manufacturer's assessment of food quality). At retail, there is a distinction between the grocery store and supermarket. 'Grocery stores' sell only food items and 'supermarkets' sell food and non-food items. However, this distinction is often blurred. The last phase of the food supply chain is the consumer who wastes food by over-stocking pantries, allowing perishables to rot, preparing excess food for meals, and misunderstanding sell-by dates. Food waste in this literature review is quantified by monetary value or percentages of total food produced per sector.

\section{Food waste, world population, and hunger}

Approximately $40 \%$ of food waste in industrialized countries is from retail and consumer levels, equivalent to the total net food production of sub-Saharan Africa (Gustavsson et al. 2011). In 2014, US food waste comprised $14.9 \%$ of 258 million metric tons (MMT) of municipal solid waste (MSW). Of the $14.9 \%$ (38.4 MMT), 1.96 MT were composted, 7.13 MT were combusted with energy recovery, and 29.3 MT were deposited in landfills (US-EPA 2016b). Other sources noted that 42.3 MMT or up to $103 \mathrm{MMT}$ of food are landfilled yearly in the US (Gustavsson et al. 2011; FWRA 2014).

Food waste and food security are competing forces that require further research and attention to be reconciled. Not only will nearly $70 \%$ of the world's population be urbanites by 2050 , the total number of people is predicted to rise to more than 9 billion (UN 2018). When considering that as of 2015 , one in nine people was chronically malnourished, future sustainable food sources do not seem promising without interventions (Pandey et al. 2016; FAO et al. 2017). The number of malnourished people rose from 777 million in 2015 to 815 million in 2016 (FAO et al. 2017). The World Health Organization (WHO) also reported that in 2016, there were 155 million children in the world with stunted growth due to prenatal, intrauterine, and postnatal malnutrition (FAO et al. 2017). Stunted growth was defined as a child who was -2 standard deviations from the WHO Child Growth Standard median (de Onis et al. 2011). Stunted growth not only results in a below median height, but there are also negative cognitive and immune effects. Women who are malnourished during pregnancy are likely unable to find adequate nutrients to support themselves and their babies. The likelihood of their children finding better nutritional resources in severely deficient areas of the world is very low unless external aid is provided.

The severity of the food crisis is high and far-reaching. Even in developed countries, like the US, 50 million people were food insecure in 2011; 16 million of the 50 million were children (FWRA 2014). The 50 million food insecure people accounted for $14.9 \%$ of households in the US; however, the homeless were not included, causing an underestimation of food insecure individuals (Coleman-Jensen et al. 2012). It should be noted that prevalence of food insecurity in a country like the US (and possibly, worldwide) is often a matter of disproportioned distribution of food and speaks more to social/political/economic issues along with behaviors toward food rather than availability of food.

While distribution is a major issue, it is also recognized that world hunger and malnourishment, whether in developing or developed countries, goes hand in hand with the global food waste crisis. It is estimated that of the 3.99 billion metric tons (MT) of food (as-is) produced in the world each year, 1.3 billion MT were diverted into landfills (Gustavsson et al. 2011). Generally, food waste from inedible plant parts, bones, blood, and skin is estimated to have approximately $4 \mathrm{kcal}$ of energy/g dry matter (Benedict and Farr 1931; Banks and Collison 1981; Sehgal and Thomas 1987; Tchobanoglus et al. 1993; Griffin et al. 2009; Lipinski et al. 2013). Based on available energy from the 1.3 billion MT of annually discarded food and a recommended $2000 \mathrm{kcal} /$ day/person, without any other losses, 2.6 billion people could be fed from yearly food waste. This would significantly reduce the $22.9 \%$ of stunted children reported in 
2016 because this condition can be prevented by adequate nutrition from conception to 2 years of age (FAO et al. 2017). In the US, a 15\% diversion of edible food waste would aid in feeding 35\% of those who are food insecure (Walia and Sanders 2017). Greater human energy from discarded food would be available if the additional energy required to produce the wasted food products was included. For example, in the US, over $25 \%$ of the total used freshwater and 300 million barrels of oil are involved in creating food waste (Buzby and Hyman 2012). Due to severe effects of food waste in industrialized countries, the US, and its top food-producing state (California), every cause of food waste in each sector of the food chain is important.

\section{Food waste along the food supply chain}

\section{Harvest sector}

The harvest sector, having helped to shape consumer expectations for 'perfect' fruits and vegetables, is now driven to meet the demand. Farmers produce crops and animal products that are utilized around the globe. To be best equipped to supply the desired goods, it is critical to know the final destination of the products prior to production. However, in certain circumstances, this results in a tremendous amount of waste due to outgrading and cosmetic restrictions. For example, on a United Kingdom (UK) carrot farm, 30-40\% of edible carrots are sorted and diverted to livestock feed. Rejected carrots have unpleasant esthetics such as slightly bent, crooked, blemished, or offcolored. One reason for rejecting misshapen carrots is that farmers, having created the demand, need carrots that can be easily and completely peeled by machine or by hand (Stuart 2009). The European Union (EU-28) reported 9.1 \pm 1.5 MMT (11\% of total food waste) of food waste in 2012 (Fig. 1; Stenmarck et al. 2016).
The harvest sector is also affected by climate change, which may lead to waste and a decrease in the availability of food. In recent years, areas of the world such as the US, the Caribbean, Africa, and South Asia have experienced hurricanes, droughts, and floods, respectively (IFPRI 2018). These occurrences have caused soil and water stresses which negatively impact both quantity and quality of food; the risk for continuation of such trends is high (Rosenzweig et al. 2001; Deryng et al. 2014). The lack of food availability due to climate change supports the international call to limit food waste (AB 32 2006; AB No. 1826 2014; Lewis et al. 2017).

As the top producer of crops and livestock in the US by revenue produced, California contributes $11 \%$ of the total national food production (USDA-ERS 2012). In 2012, 15\% of tree fruits, $5 \%$ of head lettuce, and $13 \%$ of broccoli were left unharvested (NRDC 2012). Unharvested food could be provided to citizens in California. In addition, the unharvested food becomes waste and does not benefit farmers in California. The production of food is expensive, especially when considering that California farmers spent US $\$ 34.2$ billion in 2016 on feed, farm services, livestock, labor, rent, fertilizer, and other farm expenditures (USDA-NASS 2016). The cost of labor on farms in California has also increased by US $\$ 2.3$ billion from 2015 to 2016 (USDA-NASS 2016). In conjunction with the rising cost of labor and tipping fees (money paid to landfills for discarding waste) farmers will choose the less expensive option to leave the produce on the field (BSR 2014).

\section{Process/manufacture sector}

In the past, the UK produced 2.6 MMT of food waste from the food, drink, manufacturing, and processing sectors (Lee et al. 2010). Of the 2.6 MMT, $84.6 \%$ was diverted to animal feed (Lee et al. 2010). Food waste from the manufacturing sector within the EU-28 totaled approximately 16.9 MMT in 2012, comprising $19 \%$ of all food waste in the EU-28
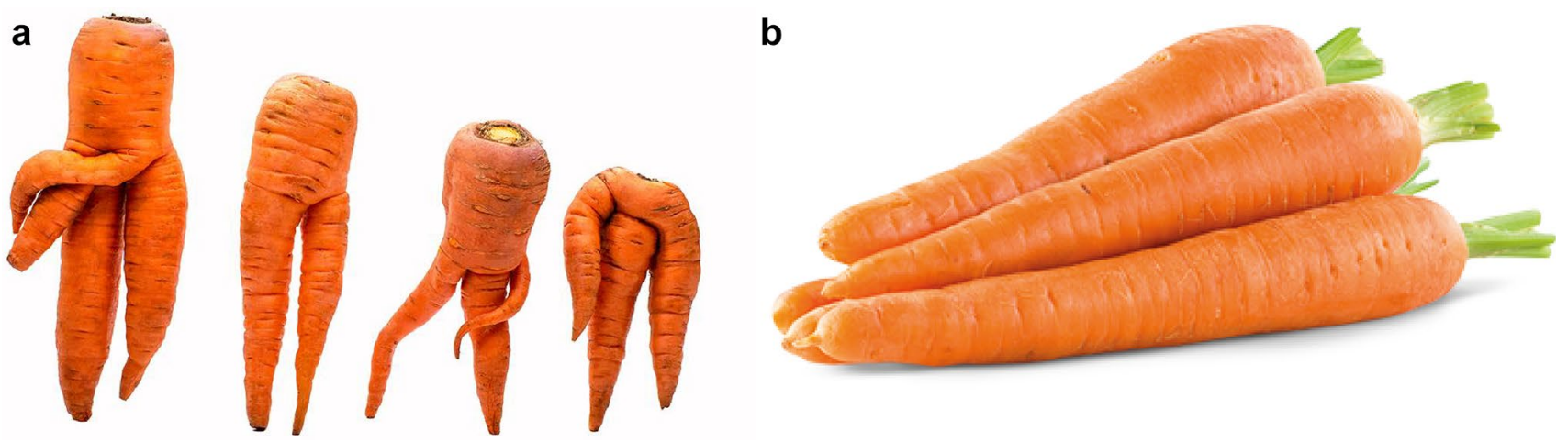

Fig. 1 Imperfect carrots which are sorted out and diverted to non-human uses or waste. a Oddly shaped carrots which are discarded after harvesting (Settembre 2018). b The typical carrot conformation which consumers want (PlusPng) 
(Stenmarck et al. 2016). Food waste and all its associated factors cost EU-28 143 billion euros in 2012, equating to more than US $\$ 168$ billion (Stenmarck et al. 2016).

During the processing and manufacturing stage, there are many unavoidable food losses such as bones and scales from meat products, and peels and pulp from fruits and vegetables. For 2016, the total annual quantity of unavoidable waste in the US from processing and manufacturing of fruits, vegetables, dairy, meat, grains, eggs, and other items was 35.9 MMT (Dou et al. 2016). When added to avoidable food waste, the total was approximately 80 MMT from 27,400 processing and manufacturing locations across the US (Dou et al. 2016). In the US manufacturing sector, approximately $96.8 \%$ of food waste was recycled, $1.5 \%$ was donated, and $1.7 \%$ was disposed in landfills (FWRA 2016). The high percentage of recycling in 2016 was greater than that of $94.9 \%$ reported in a 2013 survey of 16 US manufacturing companies that represented US\$137 billion in annual sales (BSR 2014).

Within the processing/manufacturing sector of California, food disposal has been reported at $38 \%$, comprising 0.22 MMT (CalRecycle 2015b). However, an additional 0.16 MMT were diverted to either animal feed, composting, or anaerobic digestion (CalRecycle 2015b). Due to the 0.22 MMT of food waste produced by the processing/manufacturing sector, it has been mandated by law that facilities which generated "eight or more cubic yards of organic waste in 2016, four or more cubic yards of organic waste in 2017, and four or more cubic yards of commercial solid waste in 2019” must recycle (AB No. 1826 2014; CalRecycle 2015b).

\section{Wholesale/retail sector}

The retail and wholesale sector are very similar in that customers have the ability to purchase food items. Within the retail sector, there are also specialized stores for convenience (bakeries, delicatessens, butchers, fruits, and vegetables).

Reasons reported for wholesale waste included product and packaging damage, temperature/storage in non-compliance with food safety regulations, blemishes on produce, and incorrect predictions of demand. In a UK grocery store chain, $70 \%$ of food was discarded (Stuart 2009). In a study completed by New South Wales Environmental Protection Authority, $79 \%$ of food waste produced from retail trade was landfilled in 2014 . Of the $79 \%$ of food waste, $11.5 \%$ was from meat/fish/poultry stores, $15.8 \%$ from fresh fruits and vegetables stores, $38.6 \%$ from supermarkets and grocery stores, and $34.1 \%$ from other specialized food stores (Lewis et al. 2017). In a study completed in Australia, $98 \%$ of wholesale food waste was landfilled whereas only $2 \%$ was recycled (Lewis et al. 2017). The EU-28 reported $15.1 \pm 2.7$ MMT (17\% of total food waste) of food waste from the wholesale/retail sector in 2012 (Fig. 2; Stenmarck et al. 2016).

As the main intermediaries between producers and consumers, grocery stores or supermarkets are of utmost importance to a majority of people living in centralized US locations and elsewhere. The transition of food from farms to consumers requires long traveling distances, many processing procedures, equipment, laborers, and time. As urbanization increases, the distance and process for providing the necessary food supply to dense populations will also increase. The food will have to supply over 181 million people living in areas with populations of over 500,000 in the US, also known as megacities (UN 2018). A portion of the $18 \%$ US population living in rural settings will be responsible for helping to supply the food necessary to feed much of the country and other parts of the world (FAO et al. 2017). The increasing trend of multi-national grocery stores due to the increased global trade market is also putting more pressure on farmers to produce more than they were prior to globalization of the food network (Parfitt et al. 2010).

195 MMT of food was available to retailers and consumers in 2010-2 and 19.5 MMT (10\%) of that food was lost at the retail level (Buzby et al. 2014; Dou et al. 2016). An Upstate New York grocery store, disposing of over 400 US pounds of food weekly, is likely representative (Griffin et al. 2009). In a 2013 survey of 13 respondents, accounting for $31.8 \%$ of the retail and wholesale sales in the US, it was noted that $42.4 \%$ of food waste was donated or recycled (BSR 2014). Others reported that $54.3 \%$ of wholesale food was recycled (FWRA 2016). As with the wholesale sector, the food wasted in the retail sector was due to damaged packaging, dented cans, and unsold blemished products (Parfitt et al. 2010).

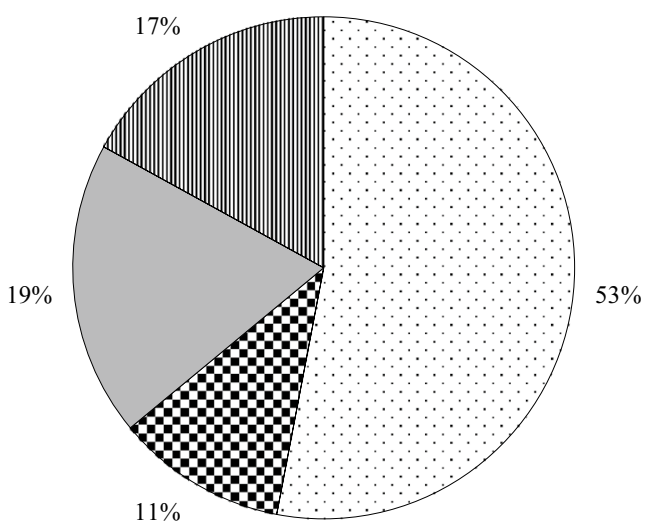

$\ulcorner$ Household $\quad$ ¿Harvest $\square$ Processing/Manufacturing $\quad$ m Wholesale/Retail

Fig. 2 Proportion of food waste by sector in the EU-28 in 2012 (Stenmarck et al. 2016) 
Another cause of many discarded food items is the sell-by date. These dates are on packages as industry's measurements of food quality, not food safety. Therefore, when consumers are unaware of the true meaning, they tend to err on the side of caution and regard these dates as expiration dates. Outdated items are not purchased or, if in home storage, are deemed unsafe to eat; both actions lead to waste (Tsiros and Heilman 2005).

In California, restaurants, food and beverage stores, and other retail trade disposed 2.07 MMT of waste in 2014 (CalRecycle 2015b). The amount of waste generated by this sector contributed to the high levels of decaying food in landfills and exacerbated greenhouse gas emissions. To comply with Assembly Bill No. 32, California has implemented stringent guidelines to decrease greenhouse gas emissions (AB 32 2006). The bill emphasizes a state-wide limit on emissions of greenhouse gasses by 2020 . Therefore, all sectors of the food supply chain will need to decrease food waste.

\section{Consumers sector}

The global waste produced by the consumer sector was estimated at approximately $19 \%$ of all edible food supply (Buzby and Hyman 2012). The amount of food wasted equaled to US\$11.8 billion (Buzby and Hyman 2012). In the UK, it was estimated that 7.2 MMT of food and drink were discarded from households yearly (Buzby and Hyman 2012). Much of the consumers' waste came directly from the plate, equating to approximately $30 \%$ of avoidable food waste in the UK. In the EU-28, 53\% (46.5 \pm 4.4 MMT) of all food waste came from the consumer sector (Fig. 2; Stenmarck et al. 2016).

The plate waste documented in US school programs for 9- to 13-year-old children ranged from 9 to $28 \%$, depending on where measurements were taken and the subjects (Martin et al. 2007, 2010; Roe et al. 2018). Additionally, it was estimated that $12.6 \%$ of US household expenditures in 2016 were spent on food, thus making it the third highest behind housing and transportation (USDA-ERS 2017). Earlier, it was estimated that $124 \mathrm{~kg}$ of food per capita was discarded (Buzby and Hyman 2012). When converted to total metric tons for an earlier US population of 311.6 million, this was approximately 41.75 MMT, which is in agreement with the 41 MMT reported by other sources (USDA-ERS 2015). Food continues to be discarded by consumers due to plate scrapings, excess holiday foods, food preferences, misunderstanding of sell-by dates, and spoilage of overstocked foods (Parfitt et al. 2010; Buzby and Hyman 2012). At this stage in the food chain, much of the food is wasted due to behavioral tendencies and small changes would greatly alleviate the waste.

The total annual food disposal by Californians amounted to 5.1 MT in the early 2000s (CalRecycle 2002). However,
California has become a leader in environmental protection plans for the US; therefore, it has the highest number of US households (1.34 million) participating in residential curbside food collection programs (Yepsen 2015). In San Francisco, California, US residents and businesses are also banned from discarding food into landfill waste (US-EPA 2016a).

\section{Solutions to prevent food waste}

Prevention of food waste has become a priority for top global organizations such as the Food and Agriculture Organization of the United Nations (FAO), the Food Waste Reduction Alliance (FWRA), and the World Food Programme (WFP). In 1945, the FAO was established by the United Nations (UN); one part of its mandate was to reduce food loss to combat hunger and malnutrition around the world. The FAO had a 40 -year goal to reduce the $15 \%$ estimated post-harvest loss by $50 \%$ in 1985 . Due to this goal, the Special Action Program for the Prevention of Food Losses was established. US representatives also pledged a 50\% reduction of food waste by the year 2030 (US-EPA 2016c).

The WFP was established to help end world hunger. The goal is to have Zero Hunger by 2030 (WFP 2016). Slowly moving toward the goal, the WFP distributed 3.5 MMT of food in 2016 (WFP 2016). Another program implemented by the UN is the Decade of Action on Nutrition where improvement of food security and nutrition will be met by 2030 (FAO et al. 2017). Moreover, in the Global Nutrition Summit of 2017, US\$640 million was pledged as new funding to eradicate global malnutrition (IFPRI 2018). The FWRA is an alliance of the Food Marketing Institute, the Grocery Manufacturers Association, and the National Restaurant Association. The main goals include diversion of food waste from landfills, increased food donations, and avoidance or reduction of food waste within the supply chain and operations (BSR 2014).

Reduction of landfilling food waste using other methods of decomposition is a goal in CA (CalRecycle 2016). In 2010 , less than 30 facilities in the US could aerobically process more than $50,000 \mathrm{Mg}$ of food waste annually (Levis et al. 2010). When compared to the 27 active landfills (with anaerobic processing) in California alone, 30 facilities in the entire US that are capable of digesting food waste are minimal (CalRecycle 2016). However, in California, there are 26 composting facilities, although they have different capacities (US-EPA 2016a). Modern facilities have float and sink tanks, vacuums, and magnets to remove rocks, glass, and ferrous metal. Presently, it is difficult for small-scale compost facilities (without modern equipment) to process material that is completely free of contaminants. Plastic contaminants are removed by hand, which is very labor intensive 
and not practical (Levis et al. 2010). A larger amount of food waste will be repurposed with implementation of programs that increase awareness and provide education on effects of contaminants.

Contaminants from grocery stores are of particular concern as many of the organically produced products are packaged. In two composting facilities in Canada, $10-12 \%$ of materials used for composting consist of non-degradable contaminants (plastic or packaging material) that prevented the use of digested food waste (Levis et al. 2010). If digested food were used, the high level of contamination would have led to health defects when fed to animals as sharp edges of plastic could penetrate into the stomach linings or cause obstructions in the animals' gastrointestinal tract (Peris 2003; Moser and Lee 1992; Ryan 1988). Thus, until proper equipment is developed to remove contaminants, solid food waste from grocery stores and supermarkets is not recommended for animal use. However, as discussed below in the section labeled "Food Waste as Animal Feed to Replace Corn/Soy", there are emerging opportunities for use of waste.

Government subsidies or incentives may motivate producers, retailers, and consumers to donate excess food to those in need. Incentives like the Good Samaritan Law implemented by the USDA in 1997 protect food vendors and retailers from liability of food-borne illnesses contracted from donated foods (USDA 1997). According to Feeding America, the top hunger-relief charity in the US, retail contribution to food banks was more than 0.362 MMT in 2012, making retailers the largest contributors (BSR 2014). In addition to the retail sector's contribution to food banks, the harvest sector can also help more. In an eighteen-month test, researchers concurrently picked broccoli, cauliflower, and celery with workers in fields and gathered $2585 \mathrm{MT}$ of food (NRDC 2012). This food was then donated to food banks across California.

Gleaning, as discussed above for research, can be a solution to harvest waste. After the initial harvest, concerned citizens can harvest remaining edible produce. In 2012, 7412 MT were gleaned in California by only two organizations (NRDC 2012). Additionally, a form of gleaning can be applied to grocery stores. For example, Albertsons supermarket chain developed a program to donate safe and edible fresh items such as meat, dairy, and produce that have reached the sell-by dates to local non-profit organizations (US-EPA 2014). Through this effort, daily food waste decreased from 720.3 to $45.36 \mathrm{~kg}$ (US-EPA 2014).

Another incentive for diversion of food waste from landfills is lowering fees when composting companies pickup food waste, thus eliminating a portion of MSW transported to landfills. Periodically, a tipping fee is collected from everyone for discarding waste in landfills. Typical US tipping fees are currently more than US\$50 per ton (US-EPA 2016b). Charging composting companies less for picking up greater quantities of compostable waste would help eliminate the annual cost of US\$90-100 billion on wasted food or approximately US\$600 to US\$1600 spent on food that will be discarded by a family of four (Jones 2006; Lipinski et al. 2013).

Additionally, composting more green waste may reduce the total MSW deposited in landfills. California MSW tipping fees have a median of US $\$ 45$ per ton, whereas green waste has a median of US $\$ 39$ per ton. However, disposal of green waste in landfills is lower than disposal of total MSW. The fee decreases further when green waste is composted (US\$30 per ton) or added to biomass (US\$13 per ton) (CalRecycle 2015a).

The future of biodegradable waste is receiving more attention in California with $15 \%$ of its landfills being in close proximity to compost facilities (CalRecycle 2015a). Although much of the energy utilized during the production of food waste is lost, some energy is regained through composting. Depending on the process of composting, $49.5-80.3 \mathrm{~m}^{3}$ of methane is produced, which generates about 10 gigawatt hours (GWh) of electricity in 1 year, greatly alleviating the net loss due to production of wasted food (Levis et al. 2010). The East Bay Municipal Utilities District in Oakland, California is an example of success. The waste haulers collect food from local restaurants and markets and deposit it into anaerobic digesters co-located with the waste treatment plant. In the anaerobic digester, bacteria break down the food waste and the biogas released is reused as energy for the treatment plant (US-EPA 2014).

Edible food is sometimes diverted to landfills instead of being distributed to others who need it. Cost of purchasing, separating, and diverting food may be the reason behind such actions. Perhaps consumers could use the technology found in studies such as the one conducted by Roe et al. (2018). In this study, the Remote Food Photography Method ${ }^{\circledR}$ was used by consumers at home to document their meals before and after eating. Through this technology, they assessed food waste in terms of calories and quantity. Their estimations were bolstered by obtaining information from the USDA's Food and Nutrient Database for Dietary Studies. If the harvest, processing/manufacturing, wholesale, and retail sectors were using the technology, food waste could be quantified across the food supply chain. This technology would also provide internally and externally validated data from grocery store activities, which are currently difficult to find due to possible negative publicity.

\section{Food waste as animal feed to replace corn/soy}

Corn, like soy, is of interest because it is needed for human consumption, animal feed, and biofuels. For instance, from 2015 to 2018, South Africans used 5050 MMT of corn 
for human consumption and 5300 MMT for animal feed (USDA-FAS 2017).

The price of corn will continue to increase as biofuel becomes more standardized. Although biofuel is heavily reliant on corn and soy, there are some researchers investigating the use of food waste as biofuel (Karmee and Lin 2014; Pham et al. 2014; Yang et al. 2014). However, inconsistent product and disorganized collection of food waste are challenges which are preventing it from being used as a source of biofuel (Karmee 2016).

In addition to the heavy reliance on corn as biofuel, it also remains a food source for many meat/dairy animals as the demand for protein, especially meat based, is increasing worldwide (Mumm et al. 2014). The demands for more feed crops are predicted to increase by $40 \%$ of the current harvest of corn and soybean (IFPRI 2018). In the US, 13.65 MMT of the corn produced and $37-80 \%$ of grains produced are allocated to feeding livestock (Mumm et al. 2014; Leib et al. 2016; Capehart et al. 2018). Some corn (and soy) that is needed for livestock can be offset by incorporation of food waste into animal feed. As well, the incorporation of food waste can decrease the current greenhouse gas emissions (3.7 MMT of $\mathrm{CO}_{2}$ ) from production of products directly intended for animal feed (Lee et al. 2010).

Feeding food scraps to animals has been in practice for many years. The disadvantages can entail nutrient variability among batches of food waste, possible contamination from packaging materials and bacteria, uncooked meat sources, and inconsistent supply of waste (Lee et al. 2010). However, feeding waste to animals is still feasible. For example, in 2010, 2.2 MT of food by-products were diverted to animal feed in the UK (Parfitt et al. 2010). In Australia, there were multiple major retailers who reportedly donated approximately 40,000 MT of food to farmers as animal feed (Lewis et al. 2017). The US Environmental Protection Agency formed a food recovery hierarchy which ranks the diversion of food waste to animal feed as number three, just after source reduction and feeding hungry people (BSR 2014).

In the US, reportedly, $84-86.8 \%$ of food waste was diverted to either animal feed or land applications from the processing/manufacturing sector, which equates to approximately 1.6 MMT of food waste converted to animal feed (BSR 2014; FWRA 2016). Furthermore, 0.17 MMT of food waste were donated from the wholesale/retailer sector (FWRA 2016). Other sources noted that 0.15 MMT or as much as 13.9 MMT of food waste were diverted to animal feed from the wholesale/retailer sector (BSR 2014; Dou et al. 2016). The efforts of MGM Grand Buffet in Las Vegas, Nevada, US are a primary example of food waste diversion into animal feed. The MGM Grand diverted 14,000 tons of pre-consumer food waste to a local farm to feed pigs. The food recovery demonstrated at the MGM saved them approximately US\$6000 to US\$8000 per month (Zanolli
2012). At the consumer level, it is estimated that only 149 MT are diverted to animal feed (BSR 2014).

Much of the food waste is given to swine and to cattle. A Minnesota company collected food scraps from restaurants, hotels, schools, nursing homes, grocery stores, and large food processors for this purpose. The customers who were serviced by this company paid $30 \%$ less than regular waste pickup for deposition in landfills (US-EPA 2014). Additionally, other researchers have compiled nutrient compositions of tropical food waste from the harvest and processing/ manufacturing sector and proposed its inclusion in pig feed (Table 1; Chedly and Lee 2001). The relative amount of each by-product can be included in the pig's diet without negative effects when compared to control diet (Table 1; Chedly and Lee 2001). In THE work of Jinno et al. (2018), comparative analysis for protein and amino in food waste from grocery stores and corn/soy was provided. As pigs are non-ruminants, their utilization of feed can be comparable to poultry; and feed ingredients which are successfully fed to pigs have high probability of use in poultry diets.

The risk of disease is the downside of feeding food scraps to some domestic animals. Geese can grind and acidify food waste more effectively than pig, chicken, or cow (personal correspondence: Klasing 2018). Since the 1980's, there has been a sharp decline in the practice of feeding food waste to some domesticated animals due to disease outbreaks (Leib et al. 2016). By 2007, only $3 \%$ of US swine farms fed food waste to their pigs (Leib et al. 2016). Thus, laws in many states of the US prohibit food waste from being fed to animals with the exception of swine (Leib et al. 2016). Georgia's Code Ann. §§ 4-4-20-24 (2015) prohibits feeding of garbage to animals except swine and Illinois' 720 Ill. Comp. Stat. § 5/48-7 (2015) prohibits feeding waste to animals with the exception of allowing household waste for swine (Leib et al. 2016). With the realization of disease spread through contaminated feed, strict laws such as the one in Georgia were adopted in all US states (Leib et al. 2016).

The practice of feeding food waste to animals has not been completely abandoned. The US now has many processing and feed production facilities that convert food waste to animal feed from various food supply chain sectors, such as harvest and processing/manufacturing. In Minnesota, the Minn. Stat. §§ 35.73-0.78 (2015) allows the feeding of treated animal derived and vegetable waste to livestock and poultry (Leib et al. 2016). The waste must be either heated (minimum of $100{ }^{\circ} \mathrm{C}$ ), boiled (minimum of $30 \mathrm{~min}$ ), or treated through other methods approved by the Board of Animal Health in Minnesota (Leib et al. 2016). California and New York have similar laws. The California Food and Agriculture Code $\S \S 32,10,901-90,34,006$ (2015) mandates that pasteurized milk and heat-treated animal-derived waste are allowed for swine consumption. Swine producers may choose to feed household waste to swine without prior heat 
Table 1 Tropical by-products proposed for silage for pig feedstuff (Chedly and Lee 2001)

\begin{tabular}{|c|c|c|c|c|c|c|c|c|}
\hline \multirow[t]{2}{*}{ Feed } & \multirow[t]{2}{*}{$\mathrm{DM}(\%)$} & \multicolumn{3}{|l|}{ Per kg DM } & \multicolumn{3}{|c|}{ Per kg fresh matter } & \multirow{2}{*}{$\begin{array}{l}\text { Inclusion rate fresh } \\
(\mathrm{kg} / \text { day })\end{array}$} \\
\hline & & $\mathrm{ME}(\mathrm{MJ} / \mathrm{kg})$ & $\mathrm{CP}(\mathrm{g} / \mathrm{kg})$ & $\mathrm{CF}(\mathrm{g} / \mathrm{kg})$ & $\mathrm{ME}(\mathrm{MJ} / \mathrm{kg})$ & $\mathrm{CP}(\mathrm{g} / \mathrm{kg})$ & $\mathrm{CF}(\mathrm{g} / \mathrm{kg})$ & \\
\hline Spent grain & 22.0 & 8.2 & 260 & 130 & 1.8 & 57.2 & 28.6 & $5-20$ \\
\hline Banana stems & 9.5 & 5.5 & 20 & 210 & 0.52 & 1.9 & 20.0 & $5-10$ \\
\hline Banana skin (ripe) & 15.0 & 6.7 & 42 & 77 & 1.0 & 6.3 & 11.6 & $2-5$ \\
\hline Rejected banana (ripe) & 30.0 & 11.5 & 54 & 22 & 3.5 & 16.2 & 6.6 & $2-5$ \\
\hline Cassava leaves & 16.0 & 6.7 & 235 & 190 & 1.1 & 37.6 & 30.4 & $3-6$ \\
\hline Cassava roots & 28.5 & 12.5 & 16 & 52 & 3.6 & 4.6 & 14.8 & $5-15$ \\
\hline Molasses & 78.0 & 11.5 & 15 & 0.00 & 9.0 & 11.7 & 0 & $0.5-2$ \\
\hline Breadfruit (ripe fruit) & 29.8 & 10.8 & 57 & 49 & 3.2 & 17.0 & 14.6 & $4-8$ \\
\hline Taro leaves & 16.0 & 6.2 & 223 & 114 & 1.0 & 35.7 & 18.2 & $1-2$ \\
\hline Taro Roots & 25.0 & 13.2 & 45 & 20 & 3.3 & 11.25 & 5 & $2-5$ \\
\hline Sweet potato (leaves) & 12.0 & 5.8 & 200 & 145 & 0.7 & 24.0 & 17.4 & $10-20$ \\
\hline Sweet potato (tuber) & 30.0 & 13.5 & 70 & 25 & 4.1 & 21.0 & 7.5 & $5-10$ \\
\hline Yam (leaves) & 24.0 & 7.3 & 120 & 250 & 1.8 & 28.8 & 60 & $2-5$ \\
\hline Yam (root) & 34.0 & 13.5 & 80 & 25 & 4.6 & 27.2 & 8.5 & $2-5$ \\
\hline Olive cake & 45.5 & 3.8 & 40 & 465 & 1.7 & 18.2 & 211.6 & $2-4$ \\
\hline Olive leaves & 56.8 & 5.7 & 105 & 300 & 3.2 & 59.6 & 170.4 & $3-6$ \\
\hline Grape marc & 37.1 & 4.9 & 138 & 410 & 1.8 & 51.2 & 152.1 & $1-3$ \\
\hline Sugar beet pulp & 19.5 & 9.8 & 91 & 316 & 1.9 & 17.4 & 61.6 & up to 20 \\
\hline Tomato pulp & 22.5 & 8.0 & 215 & 350 & 1.8 & 48.4 & 78.8 & up to 15 \\
\hline Wheat bran & 89.1 & 8.1 & 160 & 137 & 7.3 & 142.6 & 122.1 & $1-3$ \\
\hline Date palm fruit & 87.6 & 12.0 & 32 & 50 & 10.5 & 28.0 & 43.8 & $0.5-1$ \\
\hline Citrus pulp & 23 & 10.3 & 75 & 200 & 2.4 & 17.3 & 46 & up to 15 \\
\hline
\end{tabular}

$D M$ dry matter, $M E$ metabolizable energy, $C P$ crude protein, $C F$ crude fiber

treatment and without a permit (Leib et al. 2016). Facilities that choose to feed food waste to swine are required to have a permit to do so, although this excludes feeding of household food scraps.

\section{Broiler chicken and food waste}

Poultry is a prominent part of livestock. Chickens are in such high demand because they are hardy creatures that grow relatively fast in most areas of the world. Chicken meat and eggs are one of the main sources of protein for many people in the world, as is evident in the 25.2 MMT of chicken produced in 2017 by the US alone and the predicted 83.9 MMT of broiler production worldwide in 2018 (USDA-NASS 2018; USDA-FAS 2018). There is also increasing demand for meat in countries such as China where 12 MMT of chicken were produced in 2007 and 11.48 MMT of chicken were produced in 2017 (Parfitt et al. 2010; Gustavsson et al. 2011; USDAFAS 2018). Broiler production in China decreased slightly to 11.0 MMT due to avian influenza outbreaks in 2017 (Inouye 2017). It is predicted that global meat production will grow by $66 \%$ and developed country's meat production will grow by $78 \%$ by 2050 (IFPRI 2018).
In the US, export of poultry meat has grown by $225 \%$ since 1997 (Davis et al. 2013). By 2013, US broiler meat was exported to 150 countries worldwide (Davis et al. 2013). The high demand for these birds stemmed from US genetic breeding programs that produce large quantities of meat desired by consumers in many countries that import whole birds or parts (Davis et al. 2013). Chicken meat surpassed pork and beef as highest carcass weight purchased per capita in 2012 and the trend has continued (Davis et al. 2013; USDA-FAS 2018). As the second largest exporter of broiler meat with $30 \%$ of worldwide broiler production, the US broiler meat industry is predicted to increase in value by $17 \%$; this equates to US $\$ 30.2$ billion (USDA-NASS 2018; USDA-FAS 2018). The 19.2 MMT prediction for US broiler meat production in 2018 is lower than the numbers reported in 2017; however, there is strong growth in the broiler breeder inventory (USDA-ERS 2018a).

The 2019 forecast of broiler chicken growth is an increase of $2.3 \%$ due to reports of new production facilities currently under construction (Ha 2018). The increase in broiler production will equate to $1.97 \mathrm{MMT}$ of chicken (Ha 2018). With the average slaughter weight of $2.83 \mathrm{~kg}$ and US\$0.44-US\$0.48 per kg, it is predicted that the broiler industry will equate to approximately US\$938 million in 
2019 (Ha 2018). With only 38-41 federally inspected broiler chicken producers in the US, there is high demand from each producer (Davis et al. 2013; USDA-NASS 2015). The expanding broiler industry is heavily reliant on corn and soy as their main sources of feed.

The dependence on corn/soy in the US and in regions of the world where there is limited availability of both grains makes it essential to investigate the effects of various feed stuffs on poultry production. As reported by Rondon and Ashitey (2011), the effect of fluctuating prices for corn and soy can influence broiler production in countries such as Ghana where domestic poultry production declined due to rising prices in corn and flooding of cheaper product from the EU (Rondon and Ashitey 2011). Many food waste products in Ghana and other countries can be diverted to animal feed for laying hens and broilers.

The main concerns with feeding food waste to broilers are high ligno-cellulosic content (King 2013). This investigator proposed that methods of digesting the high cellulose content in plants may be feasible for many small-scale farmers around the world. For example, an established method such as ensiling only requires certain bacteria (lactic acid bacteria) to digest cellulose and hemicellulose and time for the digestion to occur (King 2013; Ni et al. 2015). The processing of food waste as poultry feed is also of importance because moldy feed will have decreased nutrient composition and pose risks to animal health. As such, drying or fermenting food waste is a practice that staunches mold growth and should be considered when incorporating food waste into poultry feed. Drying food waste as a means of preservation will require $250-300 \mathrm{~L}$ of fuel and $200 \mathrm{kWh}$ of electricity for 1 ton of dehydrated product (88-90\% dry matter) (Chedly and Lee 2001). However, ensiling preserves food while retaining many of the nutrients.

Energy, crude protein, and crude fiber are a few nutrients that are important to balance in broiler and layer diets. Therefore, when evaluating food waste products for use in chicken diets, nutrient composition must be analyzed (Table 2). A well formulated diet based on the requirements of the animal and the nutrient analyses of the feed ingredients may lead to increased feed conversion ratio in the animals. As demonstrated in multiple studies, broilers fed food waste at varying percentages had significantly similar performances when compared to a regular corn and soy diet (Table 3; Damron et al. 1965; Al-Tulaihan et al. 2004; Joshi et al. 2000; Wadhwa et al. 2013; Stefanello et al. 2016). Table 3 includes waste products from multiple sectors of the food supply chain. Dried, ground carrot, and oyster mushroom waste are from the harvesting sector. Dried tomato pomace, carrot top hay, cornflakes waste, and meat meal are from the manufacturing/processing sector. Bakery waste and leftover Korean food are from the consumer sector. The

Table 3 Level of incorporation (\% DM) of fruits and vegetables in broiler and layer diets which will yield comparable production as a $100 \%$ corn/soy diet (vitamins and minerals were added where necessary)

\begin{tabular}{lll}
\hline Feed & Broiler diet & Layer diet \\
\hline Bakery waste $^{\mathrm{a}}$ & $10-20 \%$ in starter & - \\
Dried tomato pomace $^{\mathrm{b}}$ & $5 \%$ in starter, 10\% in finisher & $10-20 \%$ \\
Dried, ground carrot $^{\mathrm{c}}$ & - & $4-8 \%$ \\
Carrot-tops hay $^{\mathrm{b}}$ & - & \multicolumn{1}{c}{$5 \%$} \\
Cornflakes waste $^{\mathrm{c}}$ & $20-60 \%$ in starter & - \\
Oyster mushroom waste $^{\mathrm{d}}$ & $1 \%$ in starter, grower, and & - \\
& finisher & - \\
Meat meal $^{\mathrm{e}}$ & $0.8 \%$ in grower, finisher & - \\
Leftover Korean food $^{\mathrm{f}}$ & $10 \%$ in starter, 30\% in finisher & - \\
\hline
\end{tabular}

${ }^{\text {a }}$ Stefanello et al. (2016)

${ }^{\mathrm{b}}$ Bakshi et al. (2016)

${ }^{\mathrm{c}}$ Ayanwale and Aya (2006)

${ }^{\mathrm{d}}$ Fard et al. (2014)

${ }^{\mathrm{e}}$ Navidshad et al. (2009)

${ }^{\mathrm{f}}$ Cho et al. (2004)
Table 2 Energy ( $\mathrm{kcal} / \mathrm{kg}$ ), crude protein $(\mathrm{g} / \mathrm{kg})$, and crude fiber $(\mathrm{g} / \mathrm{kg})$ of various feedstuff for broiler chicken and laying hens

\begin{tabular}{lllllc}
\hline Feed & DM $(\%)$ & GE $(\mathrm{kcal} / \mathrm{kg})$ & $\mathrm{ME}(\mathrm{kcal} / \mathrm{kg})$ & $\mathrm{CP}(\mathrm{g} / \mathrm{kg})$ & $\mathrm{CF}(\mathrm{g} / \mathrm{kg})$ \\
\hline Bakery waste $^{\mathrm{a}}$ & 89.6 & 4136.0 & - & 132.0 & 33.8 \\
Tomato pomace $^{\mathrm{b}}$ & 25.3 & - & - & $190.0-221.0$ & $1014.0-1140.0$ \\
Carrot and carrot pulp $^{\mathrm{b}}$ & $9.5-10.1$ & - & - & $72.0-99.0$ & $17.0-44.0$ \\
Cornflakes waste $^{\mathrm{c}}$ & 94.7 & - & 3330.0 & 6.7 & 2.7 \\
Oyster mushroom waste $^{\mathrm{d}}$ & 94.9 & - & 1270.0 & 9.9 & 32.9 \\
Meat meal $^{\mathrm{e}}$ & 39.5 & 5115.0 & 2010.0 & 298.8 & 104.0 \\
\hline
\end{tabular}

$D M$ dry matter, $G E$ gross energy, $M E$ metabolizable energy, $C P$ crude protein, $C F$ crude fiber

${ }^{\text {a }}$ Stefanello et al. (2016)

${ }^{\mathrm{b}}$ Bakshi et al. (2016)

${ }^{\mathrm{c}}$ Ayanwale and Aya (2006)

${ }^{\mathrm{d}}$ Fard et al. (2014)

${ }^{\mathrm{e}}$ Navidshad et al. (2009) 
inclusion of such feed ingredients allows participation across all sectors of the food supply chain which decreases waste accumulation in landfills.

Bakery waste has been successfully used in broiler feed (Damron et al. 1965; Al-Tulaihan et al. 2004; Stefanello et al. 2016). Damron et al. (1965) found that inclusion of up to $10 \%$ dried bakery product had no significant differences in body weights and feed conversion ratios as other 56-day-old broilers fed exclusively corn/soy. Al-Tulaihan et al. (2004) also found that inclusion of up to $30 \%$ dried bakery waste had no significant differences in body weight, feed conversion ratio, and feed intake when compared to 42-day-old broilers fed exclusively corn/soy. Navidshad et al. (2009) found that when broilers were provided meat meal at 65 and $80 \mathrm{~g} / \mathrm{kg}$ feed in a corn/soy-based diet, they had comparable daily weight gain, daily feed intake, and feed conversion ratio to birds fed with a full corn/soy diet. Moreover, results of studies using waste from fermented fish, various fruits and vegetables, fermented apple pomace, and dried leftover Korean food support their use in broiler diets (Hammoumi et al. 1997; Joshi et al. 2000; Wadhwa et al. 2013; Bakshi et al. 2016).

\section{Food waste utilization in California}

California is the producer of $99 \%$ or more of all US almonds, artichokes, dates, dried plums, figs, garlic, kiwifruit, olives and olive oil, pistachios, raisins, table grapes, and walnuts (CDFA 2017). Thus, California, exporting 26\% of its agricultural production, provides nutrients to many around the world (CDFA 2017). With the high amount of food produced in California for domestic use and export, food waste accounted for 15\% of its MSW in 2008 (CalRecycle 2015a). Therefore, the California Department of Resources Recycling has a goal to recycle $75 \%$ of the materials that are currently being landfilled by 2020 (CalRecycle 2015a). As noted above, one way to recycle food waste is to use it to replace or partially replace corn and soy for meat production.

Recent technologies have been aimed to recycle food waste in California. One such technology utilized food waste from supermarkets $(80.5 \mathrm{~km}$ radius $)$ and specialty stores to create solid and liquid products. This patented process also rendered the food waste pathogen-free with a consistent availability of nutrients (US Patent numbers 9388088, 9416062, and 9643895; Jinno et al. 2018). The process includes enzymatic digestion at $55-57^{\circ} \mathrm{C}$, pasteurization at 75-77 ${ }^{\circ} \mathrm{C}$, filtering, and $\mathrm{pH}$ stabilization to $\mathrm{pH} 2.8-3.0 \mathrm{using}$ phosphoric acid. The solid materials are separated from the liquid material, used as a fertilizer (Pandey et al. 2016). This specific process has the capability of recovering $90 \%$ of the original food waste. The remaining $10 \%$ of the material is discarded as solid waste.
The enzymatically digested food waste was highly effective in promoting growth of strawberries, almonds, leafy greens, tomatoes, and wine grapes (Duarte 2014; Pandey et al. 2016; CSS 2018). Through field studies, the liquidized food waste increased strawberry yield by $40 \%$ whereas commercial fertilizers produced a 25\% increase (Dara 2013; Pandey et al. 2016). The roots and the marketable weight of the strawberries were similar or higher when compared to standard fertilizers (Dara 2013).

The same enzymatically digested food waste was fed to 56 growing-finishing pigs (Jinno et al. 2018). There was no significant difference between pigs fed regular corn and soy diets and those fed the processed food waste diet; therefore, results indicated that the processed food waste may provide the necessary nutrients to growing-finishing pigs (Jinno et al. 2018). As chicken and pigs are both monogastric animals, it will be beneficial to investigate the use of the processed food waste as a substitute for a portion of corn and soy in chicken diets.

\section{Conclusion}

The proposed use of food waste can partially mitigate issues of hunger, environmental contamination, and economic loss in California. Utilization of food waste as animal (especially chicken) feed can divert it from landfills while providing nutrients to animals and subsequently humans, and may become a model for its use elsewhere.

Acknowledgements This work was supported by California Safe Soil, LLC (CSS).

\section{Compliance with ethical standards}

Conflict of interest The authors declare that they have no conflict of interest.

Open Access This article is distributed under the terms of the Creative Commons Attribution 4.0 International License (http://creativeco mmons.org/licenses/by/4.0/), which permits unrestricted use, distribution, and reproduction in any medium, provided you give appropriate credit to the original author(s) and the source, provide a link to the Creative Commons license, and indicate if changes were made.

\section{References}

Al-Tulaihan A, Najib H, Al-Eid S (2004) The nutritional evaluation of locally produced dried bakery waste (DBW) in the broiler diets. Pak J Nutr 3:294-299. https://doi.org/10.3923/pjn.2004.294.299

Assembly Bill No. 1826 (2014) California integrated waste management act of 1989

Assembly Bill No. 32 (2006) California global warming solutions act of 2006 
Ayanwale B, Aya V (2006) Nutritional evaluation of cornflakes waste in diets of broilers. Pak J Nutr 5:485-489. https://doi.org/10.3923/ pjn.2006.485.489

Bakshi M, Wadhwa M, Makkar P (2016) Waste to worth: vegetable wastes as animal feed. CAB Rev Perspect Agri Vet Sci Nutr Nat Resour 11:1-26. https://doi.org/10.1079/PAVSNNR201611012

Banks G, Collison R (1981) Food waste in catering. Can Inst Food Sci Technol J 14:181-189

Bellemare M, Çakir M, Peterson H, Novak L, Rudi J (2017) On the measurement of food waste. Am J Agri Econ 99:1148-1158. https ://doi.org/10.1093/ajae/aax034

Benedict F, Farr A (1931) The energy and protein content of edible food waste and mixed meals in sorority and fraternity houses. New Hamps Agric Exp Stn Bull 26:261

BSR (2014) Analysis of US food waste among food manufacturers, retailers, and restaurants. Business for social responsibility. https ://www.foodwastealliance.org/wp-content/uploads/2014/11/ FWRA_BSR_Tier3_FINAL.pdf. Accessed 30 May 2019

Buzby J, Hyman J (2012) Total and per capita value of food loss in the United States. Food Policy 37:561-570. https://doi.org/10.1016/j. foodpol.2012.06.002

Buzby J, Wells H, Hyman J (2014) The estimated amount, value, and calories of postharvest food losses at the retail and consumer levels in the United States, EIB-121. USDA- Economic Research Service, Washington

CalRecycle (2002) Food waste recovery: a model for local government recycling and waste reduction. The California Integrated Waste Management Board, Sacramento

CalRecycle (2015a) Landfill tipping fees in California. California Department of Resources, Recycling, and Recovery, Sacramento

CalRecycle (2015b) 2014 Generator-based characterization of commercial sector disposal and diversion in california. California Department of Resources Recycling and Recovery, Sacramento

CalRecycle (2016) State of disposal in California-updated 2016. California Department of Resources, Recycling, and Recovery, Sacramento

Capehart T, Liefert O, Olson D (2018) Feed outlook, May 2018. Economic research service- situation and outlook report. FDS-18e. USDA-Economic Research Service, Washington

CDFA (2017) California agricultural statistics review, 2016-2017. California Department of Food and Agriculture, Sacramento

Chedly K, Lee S (2001) Paper 6: silage from by-products for smallholders. FAO corporate document repository. Available from http:// www.fao.org/DOCREP/005/X8486E/x8486e01.htm. Accessed 30 May 2019

Cho Y, Lee G, Jang J, Shin I, Myung K, Choi K, Bae I, Yang C (2004) Effects of feeding dried leftover food on growth and body composition of broiler chicks. Asian-Aust J Anim Sci 17:386-393. https ://doi.org/10.5713/ajas.2004.386

Coleman-Jensen A, Nord M, Andrews M, Carlson S (2012) Household food security in the United States in 2011. Economic research report number 141. USDA-Economic Research Service, Washington

PlusPng. http://pluspng.com/png-117302.html. Accessed May 302019

CSS (2018) Conventional agriculture. https://www.calsafesoil.com/ conventional-agriculture. Accessed 30 May 2019

Damron B, Waldroup P, Harms R (1965) Evaluation of dried bakery products for use in broiler diets. Poult Sci 44:1122-1126. https:// doi.org/10.3382/ps.0441122

Dara S (2013) Harvesting more strawberries with harvest-to-harvest. https://www.calsafesoil.com/_literature_120775/CSS_Sprin g_2013_Strawberry_Trial. Accessed 30 May 2019

Davis C, Harvey D, Zahniser S, Gale F, Liefert W (2013) Assessing the growth of US broiler and poultry meat exports. LPDM-231-01. USDA-Economic Research Service, Washington de Onis M, Blössner M, Borghi E (2011) Prevalence and trends of stunting among pre-school children. Public Health Nutr 15:142148. https://doi.org/10.1017/S1368980011001315

Deryng D, Conway D, Ramankutty N, Price F, Warren R (2014) Global crop yield response to extreme heat stress under multiple climate change futures. Environ Res Lett 9:1-13. https://doi. org/10.1088/1748-9326/9/3/034011

Dou Z, Ferguson J, Galligan D, Kelly A, Finn S, Giegengack R (2016) Assessing US food wastage and opportunities for reduction. Glob Food Secur 8:19-26. https://doi.org/10.1016/j.gfs.2016.02.001

Duarte M (2014) H2H impact on soil organic matter in an almond orchard in Kern county. https://www.calsafesoil.com/_literature _120773/CSS_2013-2014_Almond_Trials. Accessed 30 May 2019

FAO, IFAD, UNICEF, WFP, WHO (2017) The state of food security and nutrition in the world 2017. Building resilience for peace and food security. FAO, Rome, Italy. http://www.fao.org/3/a-i7695 e.pdf. Accessed 30 May 2019

Fard S, Toghyani M, Tabeidian S (2014) Effect of oyster mushroom wastes on performance, immune responses and intestinal morphology of broiler chickens. Int J Recycl Org Waste Agric 3:141146. https://doi.org/10.1007/s40093-014-0076-9

FWRA (2014) Best practices and emerging solutions toolkit. Food Waste Reduction Alliance, Washington

FWRA (2016) Analysis of US food waste among food manufacturers, retailers, and restaurants. Food Waste Reduction Alliance, Washington

Griffin M, Sobal J, Lyson T (2009) An analysis of a community food waste stream. Agric Human Values 26:67-81. https://doi. org/10.1007/s10460-008-9178-1

Gustavsson J, Cederberg C, Sonesson U, van Otterdijk R, Meybeck A (2011) Global food losses and food waste- extent, causes and prevention. FAO, Office of Knowledge, Exchange, Research and Extension, Via delle Terme di Caracalla, Rome, Italy. http://www. fao.org/3/a-i2697e.pdf. Accessed 30 May 2019

Ha K (2018) Livestock, dairy, and poultry outlook: 2019 forecast: production of beef, pork, broilers, turkey, eggs and milk expected to increase. USDA-Economic Research Service, Washington

Hammoumi A, Faid M, El yachioui M, Amarouch H (1997) Characterization of fermented fish waste used in feeding trials with broilers. Process Biochem 33:423-427. https://doi.org/10.1016/ S0032-9592(97)00092-7

IFPRI (2018) 2018 global food policy report. International Food Policy Research Institute, Washington. https://doi.org/10.2499/97808 9629297

Inouye A (2017) China-peoples republic of, poultry and products annual, avian influenza continues to affect trade CH17040. USDAForeign Agricultural Service, Washington

Jinno C, He Y, Morash D, McNamara E, Zicari S, King A, Stein H, Liu Y (2018) Enzymatic digestion turns food waste into feed for growing pigs. Anim Feed Sci Technol 242:48-58. https://doi. org/10.1016/j.anifeedsci.2018.05.006

Jones T (2006) Addressing food wastage in the US. Interview: the science show, 8 April. http://www.abc.net.au/rn/scienceshow/stori es/2006/1608131.htm. Accessed 30 May 2019

Joshi V, Gupta K, Devrajan A, Lal B, Arya S (2000) Production and evaluation of fermented apple pomace in the feed of broilers. J Food Sci Technol 37(6):609-612

Karmee S (2016) Liquid biofuels from food waste: current trends, prospect and limitation. Renew Sust Energ Rev 53(1):945-953. https ://doi.org/10.1016/j.rser.2015.09.041

Karmee S, Lin C (2014) Lipids from food waste as feedstock for biodiesel production: case Hong Kong. Lipid Technol 26:206-209. https://doi.org/10.1002/lite.201400044

King A (2013) Chapter 10: removal of excess cellulose and associated polysaccharides in fruit and vegetable by-products-implication of 
ruse in feed for monogastric farm animals. In: van de Ven TGM (eds) Cellulose fundamental aspects. http://doi.org/10.5772/53851

Lee D, Willis P, Hollins O (2010) Waste arising in the supply of food and drink to households in the UK. Waste and Resources Action Programme, Banbury

Leib E, Balkus O, Rice C, Maley M, Taneja R, Cheng R, Civita N, Alvoid T (2016) Leftovers for Livestock: A Legal Guide for Using Excess Food as Animal Feed. The Harvard Food Law and Policy Clinic and the Food Recovery Project at the University of Arkansas School of Law

Levis J, Barlaz M, Themelis N, Ulloa P (2010) Assessment of the state of food waste treatment in the United States and Canada. Waste Manag 8-9:1485-1494. https://doi.org/10.1016/j.wasma n.2010.01.031

Lewis H, Downes J, Verghese K, Young G (2017) Food waste opportunities within the food wholesale and retail sectors. Prepared for the NSW Environment Protection Authority by the Institute for Sustainable Futures at the University of Technology Sydney

Lipinski B, Hanson C, Lomax J, Kitinoja L, Waite R, Searchinger T (2013) Reducing food loss and waste. World Resource Institute. Washington, DC, USA. http://www.worldresourcesreport.org. Accessed 30 May 2019

Martin C, Newton R, Anton S, Allen H, Alfonso A, Han H, Stewart T, Sothern M, Williamson D (2007) Measurement of children's food intake with digital photography and the effects of second servings upon food intake. Eat Behav 8:148-156. https://doi. org/10.1016/j.eatbeh.2006.03.003

Martin C, Thomson J, LeBlanc M, Stewart T, Newton R, Han H, Sample A, Champagne C, Williamson D (2010) Children in school cafeterias select food containing more saturated fat and energy than the institute of medicine recommendations. J Nutr 140(9):1653-1660. https://doi.org/10.3945/jn.109.119131

Moser M, Lee D (1992) A fourteen-year survey of plastic ingestion by western north Atlantic seabirds. Colonial Water Birds 15:83-94. https://doi.org/10.2307/1521357

Mumm R, Goldsmith P, Rausch K, Stein H (2014) Land usage attributed to corn ethanol production in the United States: sensitivity to technological advances in corn grain yield, ethanol conversion, and co-product utilization. Biotechnol Biofuels 7:61. https ://doi.org/10.1186/1754-6834-7-61

Navidshad B, Adibmoradi M, Seifdavati J (2009) Effect of dietary levels of a modified meat meal on performance and small intestinal morphology of broiler chicken. Afr J Biotechnol 8:5620 5626. https://doi.org/10.4314/ajb.v8i20.66017

Ni K, Wang Y, Cai Y, Pang H (2015) Natural lactic acid bacteria population and silage fermentation of whole-crop wheat. AsianAustral J Anim Sci 28(8):1123-1132. https://doi.org/10.5713/ ajas.14.0955

NRDC (2012) Left-out: an investigation of the causes and quantities of crop shrink. NRDC, New York. https://www.nrdc.org/sites/ default/files/hea_12121201a.pdf. Accessed 30 May 2019

Pandey P, Lejeune M, Biswas S, Morash D, Weimer B, Young G (2016) A new method for converting food waste into pathogen free soil amendment for enhancing agricultural sustainability. J Clean Prod 112:205-213. https://doi.org/10.1016/j.jclep ro.2015.09.045

Parfitt J, Barthel M, Macnaughton S (2010) Food waste within food supply chains: quantification and potential for change to 2050 . Philos Trans R Soc Lond B Biol Sci 365:3065-3081. https://doi. org/10.1098/rstb.2010.0126

Peris S (2003) Feeding in urban refuse dumps: ingestion of plastic objects by the white stork (Ciconia Ciconia). Ardeola 50(1):81-88

Pham T, Kaushik R, Parshetti G, Russell M, Balasubramanian R (2014) Food-waste-to-energy conversion technologies: current status and future directions. Waste Manag 38:399-408. https:// doi.org/10.1016/j.wasman.2014.12.004
Roe B, Apolzan J, Qi D, Allen H, Martin C (2018) Plate waste of adults in the United States measured in free-living conditions. PLoS One 13:e0191813. https://doi.org/10.1371/journal.pone.0191813

Rondon M, Ashitey E (2011) Ghana: poultry and products brief. USDA-Foreign Agricultural Service, Washington

Rosenzweig C, Iglesias A, Yang X, Epstein P, Chivian E (2001) Climate change and extreme weather events: implications for food production, plant diseases, and pests. Glob Change Hum Health 2:90-104. https://doi.org/10.1023/A:1015086831467

Ryan P (1988) Effect of ingested plastic on seabird feeding: evidence from chicken. Mar Pollut Bull 19:125-128. https://doi. org/10.1016/0025-326X(88)90708-4

Sehgal H, Thomas J (1987) Efficacy of two formulated supplementary diets for carp, Cyprinus carpio Var. communis (Linn.): effects on flesh composition. Biol Wastes 21:179-186. https://doi. org/10.1016/0269-7483(87)90123-6

Settembre J (2018) Ugly produce is the new food porn. https:// www.marketwatch.com/story/ugly-produce-is-the-new-foodporn-2018-10-24-888654. Accessed 26 Feb 2019

Stefanello C, Vieira S, Xue P, Ajuwon K, Adeola O (2016) Age-related energy values of bakery meal for broiler chickens determined using the regression method. Poult Sci 95:1582-1590. https:// doi.org/10.3382/ps/pew046

Stenmarck A, Jensen C, Quested T, Moates G (2016) Estimates of European food waste levels. Tech Rep. https://doi.org/10.13140/ RG.2.1.4658.4721

Stuart T (2009) Waste: uncovering the global food scandal. New York

Tchobanoglus G, Theisen H, Vigil S (1993) Integrated solid waste management: engineering principles and management issues. New York

Tsiros M, Heilman C (2005) The effect of expiration dates and perceived risk on purchasing behavior in grocery store perishable categories. J Mark 69:114-129. https://doi.org/10.1509/ jmkg.69.2.114.60762

UN (2018) World urbanization prospects: the 2018 revision, methodology. UN-Department of economic and social affairs, population division. Working Paper No. ESA/P/WP.252. New York: United Nations

USDA (1997) A citizen's guide to food recovery. USDA, Washington

Usda-FAS (2017) South Africa grain and feed update: the supply and demand for corn in South Africa. USDA-Foreign Agricultural Service, Office of Global Analysis, Washington

USDA-ERS (2012) Market value of agricultural products sold in 2012. Farm Sector Income and Finances. USDA-Economic Research Service, Washington

USDA-ERS (2015). Food availability (per capita) data system-food availability. USDA-Economic Research Service. https://www.ers. usda.gov/data-products/food-availability-per-capita-data-system/. Accessed 30 May 2019

USDA-ERS (2017) Ag and Food Statistics- Charting the Essentials, October 2017. Economic research service-situation and outlook report number 078. USDA- Economic Research Service, Washington

USDA-ERS (2018a) Livestock, dairy, and poultry outlook: what is driving 2019 supply growth of red meats, poultry, eggs, and milk? LDP-M-288. USDA-Economic Research Service, Washington

USDA-ERS (2018b) Employment in agriculture, food, and related industries 2016. USDA- Economic Research Service, Washington

USDA-FAS (2018) Livestock and poultry: world markets and trade. USDA-Foreign Agricultural service, Office of global analysis, Washington

USDA-NASS (2015) USDA poultry production data: may 2015. USDA-National Agricultural Statistics Service, Washington

USDA-NASS (2016) US farm production expenditures, 2016. NASS highlights. USDA-national agricultural statistics service, Washington 
USDA-NASS (2018) Poultry-production and value: 2017 summary. USDA-National Agricultural Statistics Service, Washington

US-EPA (2014) Reducing wasted food and packaging: a guide for food service and restaurants. EPA-909-K-14-002. US-Environmental Protection Agency. https://www.epa.gov/sites/production /files/2015-08/documents/reducing_wasted_food_pkg_tool.pdf. Accessed 30 May 2019

US-EPA (2016a) Food waste management in the United States, 2014. Office of resource conservation and recovery, US-Environmental Protection Agency. https://www.epa.gov/sites/production/files /2016-12/documents/food_waste_management_2014_12082 016_508.pdf. Accessed 30 May 2019

US-EPA (2016b) Advancing sustainable materials management: 2014 fact sheet: assessing trends in material generation, recycling, composting, combustion with energy recovery and landfilling in the United States. US-Environmental Protection Agency, Office of Land and Emergency Management (5306P). EPA530-R-17-01. Washington, DC, USA

US-EPA (2016c). America's food waste problem. US- Environmental Protection Agency. https://www.epa.gov/sciencematters/americasfood-waste-problem. Accessed 30 May 2019

Wadhwa W, Bakshi M, Makkar H (2013) Utilization of fruit and vegetable wastes as livestock feed and as substrates for generations of other value-added products. FAO, Rome
Walia B, Sanders S (2017) Curbing food waste: a review of recent policy and action in the USA. Renew Agri Food Syst 34:1-9. https ://doi.org/10.1017/S1742170517000400

WFP (2016) Annual performance report for 2016. WFP/EB.A/2017/. World Food Programme, Rome

Yang X, Lee S, Yoo H, Shin H, Thapa L, Park C, Kim S (2014) Production of bioethanol and biodiesel using instant noodle waste. Bioprocess Biosyst Eng 37:1627-1635. https://doi.org/10.1007/ s00449-014-1135-3

Yepsen R (2015) BioCycle nationwide survey: residential food waste collection in the US. BioCycle 56:53

Zanolli A (2012) Sustainable food management in action. BioCycle $53: 48$

Publisher's Note Springer Nature remains neutral with regard to jurisdictional claims in published maps and institutional affiliations. 